\title{
From Brand Performance to Consumer Performativity - European Trade Mark Law after the Rise of Anthropological Marketing
}

Originally published as L. McDonagh, 'From Brand Performance to Consumer Performativity - European Trade Mark Law after the Rise of Anthropological Marketing,' Journal of Law and Society (2015) 42(4), 611-636.

\begin{abstract}
Since the 2009 CJEU decision in L'Oréal v Bellure the idea that a brand's image is the property of the trade mark owner has become increasingly entrenched within European trade mark law. Brand image is now protected even where there is no harm to the underlying mark. However, the courts have largely failed to acknowledge the radical ways in which the marketplace for goods bearing trade marks has changed in the past three decades. One key shift is that businesses and marketers no longer view the brand creation process from a top-down 'brand performance' perspective, but, rather, through the prisms of 'anthropological marketing' and 'consumer performativity'. Through an interdisciplinary approach, this article dissects the process of brand creation in the context of European trade mark law, and argues that the law must take account of consumer agency when the question of who should own brand image arises.
\end{abstract}




\section{INTRODUCTION}

It would be an understatement to say that European trade mark law is at something of a crossroads the truth is that the law has already moved some way down a previously unchartered path. Since the 2009 CJEU decision in L'Oréal v Bellure, the notion that the brand's image is the property of the trade mark owner - apparently justified by the investment in the mark by its owner - has become increasingly entrenched within European trade mark law. ${ }^{1}$ Indeed, the law now protects brand image even where there is no harm to the underlying mark. Yet, while the boundaries of trade mark protection have undoubtedly been expanded since 2009, the CJEU has not adequately theorised or explained why this expansion has occurred from the point of view of trade mark doctrine; nor, given the commonly accepted distinction between trade mark and brands, have the courts properly explained why it is right that trade mark owners should be able to use trade mark law to claim all aspects of valuable brand image. ${ }^{2}$ Finally, this judicial expansion of the law has occurred without any real analysis of the radical ways in which the marketplace for goods bearing trade marks has changed during the past three decades; indeed, the courts have failed to take account of the fact that there has been a paradigm shift in marketing literature and practice, from a top-down 'brand performance' perspective to a 'anthropological marketing' framework centring on 'consumer performativity' of brands and co-creation of brand image. ${ }^{3}$ The failure of the courts to provide a satisfactory explanation for the expansion of trade mark law to protect brand image raises significant questions about the nature of the relationship between trade mark law and brands, as well as the creation of brand image and its ownership. This article asks, first, who creates brand image; and second, who, if anyone, should own brand image?

In addition to providing a legal analysis of the key issues, the article attempts to answer these questions by examining relevant literature outside the legal and marketing fields, including works of feminist, sociological, and anthropological scholarship, and by reflecting on these insights to assess what role European trade mark law ought to play in the context of brand protection. ${ }^{4}$

\footnotetext{
${ }^{1}$ L'Oréal SA v Bellure NV (C-487/07) [2009] ETMR 55. See also L'Oréal v Bellure [2010] EWCA Civ 535. See also D. Gangjee and R. Burrell, 'Because you're worth it: L'Oreal and the prohibition on free-riding,' (2010) 73 Modern Law Review 282 and D.R. Desai, 'From Trademarks to Brands,' (2012) 64 Florida Law Review 981. ${ }^{2}$ T. Aplin and J. Davis, Intellectual Property Law: Texts, Cases and Materials (2nd ed: Oxford: OUP, 2013), 377-390. See also L. Bently, J. Davis and J. C. Ginsburg (eds.), Trade Marks and Brands: An Interdisciplinary Perspective (Cambridge: CUP, 2008).

${ }^{3}$ C. Grönroos, 'From marketing mix to relationship marketing: towards a paradigm shift in marketing,' (1994) 2 Asia-Australia Marketing Journal 9, 9-11. See also P. Fawkes, 'How IKEA Wins Business Through Co-creation \& Collaboration,' Professional Search For Knowledge (PSFK) - accessible at http://www.psfk.com/2014/07/ikea-brand-strategy.html

${ }^{4}$ J. Butler, 'Performative Acts and Gender Constitution: An Essay in Phenomenology and Feminist Theory,' (1988) 40 Theatre Journal 519, 519-523, M. Callon, C. Méadel and V. Rabeharisoa, 'The economy of qualities,' 
The first part of this article examines the underlying justificatory rationales of trade mark law in the context of L'Oréal and related cases, noting that the CJEU's recognition of brands as property under trade mark law marks a significant shift with respect to what the law protects. This shift is based on two questionable assumptions: first, that the TM owner's investment creates brand image; and second, that TM law ought to protect brand image. ${ }^{5}$ As explored over the course of this article, by resting its decision upon these assumptions the CJEU has failed to properly engage with the complex question of who creates brands within the consumer economy. ${ }^{6}$

The effect of this failure is that trade mark law has expanded into hitherto unchartered territory viewing brands themselves as objects of property - something that potentially impacts on competition and the rights of consumers. ${ }^{7}$ Although the subsequent interpretation of L'Oréal v Bellure at the EU and national levels indicates there is some room for judicial manoeuvre when allegations of 'freeriding' and questions of 'fair competition' arise, there is still much cause for concern - not least the apparent judicial acceptance of the notion that ownership of the trade mark automatically necessitates recognizing the trade mark owner's property in all aspects of brand image, a position that has not been subjected to a serious theoretical critique. ${ }^{8}$ Indeed, a thorough examination of how brand image is typically constructed and maintained - and how trade mark law ought to respond to claims of ownership - is required in order to unpack this development. ${ }^{9}$ Of particular importance in this regard is recognition of the fact that although there is overlap between the trade mark and the brand, it is

(2002) 31 Economy and Society 194, 194-199 and C. Nakassis, 'Brand, Citationality, Performativity,' (2012) 114 American Anthropologist 624, 629.

${ }_{5}^{5}$ D. Gangjee, 'Property in Brands - The Commodifcation of Conversation,' in H.R. Howe and J. Griffiths (eds.), Concepts of Property in Intellectual Property Law (Cambridge: CUP, 2013), 29-59, 29-30, B. Beebe, 'The Semiotic Analysis of Trade Mark Law' (2004) 51 UCLA Law Review 621 and D. Barnes, 'Trademark Externalities' (2007) 10 Yale Journal of Law \&Technology 1, 20-22.

${ }^{6}$ Ibid.

${ }^{7}$ See comments of Jacobs L.J. in L'Oréal v Bellure [2010] EWCA Civ 535 at para. 30. See generally J. Davis, 'Between a Sign and a Brand: Mapping the Boundaries of a Registered Trade Mark in European Union Trade Mark Law' in L. Bently, J. Ginsburg and J. Davis (eds.), Trade Marks and Brands: An Interdisciplinary Critique (Cambridge: CUP, 2008 ), 65-91 and M. Senftleben, 'Trade Mark Protection: A Black Hole in the Intellectual Property Galaxy?,' (2011) 42 International Review of Intellectual Property Law 383.

${ }^{8}$ See Google v. Louis Vuitton Malletier et al. (C-236/08, C-237/08 and C-238/08) [2010] ETMR 30 (Grand Chamber) and Interflora, Inc \& Anor v Marks \& Spencer Plc (Case C-323/09) [2012] ETMR 1 as well as the UK cases of Whirlpool Corp. v. Kenwood [2009] EWCA Civ. 753 at para. 135 and Specsavers International Healthcare Ltd $v$ Asda Stores Ltd (No. 2) [2012] EWCA Civ. 24 at para. 141.

${ }^{9}$ K.L. Keller, Strategic Brand Management: Building, Measuring, and Managing Brand Equity (2nd ed.: Pearson Prentice Hall: Upper Saddle River, NJ. 2003), 59-67. See also J-N. Kapferer, The New Strategic Brand Management: Creating and Sustaining Brand Equity Long Term (4th ed.: London: Kogan Page, 2008) and C. Tynan, S. McKechnie and C. Chhuon, 'Co-creating value for luxury brands,' (2010) 63 Journal of Business Research 1156. 
more accurate to view these concepts through separate lenses. ${ }^{10}$ Recent work by marketing scholars such as Keller and Kapferer, and legal scholars such as Gangjee and Desai, has added a great deal to the discourse on these issues, but much remains to be said. ${ }^{11}$

The second part of this article contributes to this ongoing discussion by drawing insights from the work of a number of scholars from outside the legal and marketing fields, namely Judith Butler, Michel Callon et al. and Constantine Nakassis. Regarding the relevance of Butler's thought in this context, it is argued here that although the connection is rarely made, much current marketing literature reflects the influence one of the key intellectual narratives that emerged following the 1970s: that is, the move away from stable, essentialist conceptions of identity towards postmodern, performative notions of the self, a societal shift analyzed in great detail in Butler's feminist scholarship. ${ }^{12}$ In tandem with the emergence of this destabilizing narrative concerning the personal 'self', Michel Callon et al.'s analysis of the 'economy of qualities' shows that notions of the consumer economy have also been destabilized - and subsequently reconstructed - in the aftermath of postmodernism, whereby businesses and marketers have moved away from a static notion of the way consumers perceive brands, towards a highly reflexive notion of the consumer economy. ${ }^{13}$ Marketers have effectively moved beyond merely asking questions about brand penetration and performance to exploring and encouraging something much more fluid: anthropological marketing.

Sometimes described as relationship marketing, anthropological marketing is a concept which focuses on the 'consumer performativity' of brands. ${ }^{14}$ This notion of consumer performativity has Butlerian roots and it further resonates with the empirical work of the anthropologist Constantine Nakassis, a scholar of brands and consumerism. ${ }^{15}$ Drawing on insights from the work of Butler, Callon, and Nakassis, this article answers the first question posed above - who creates brand image? - by showing that, contrary to the view of the CJEU, the investment of the trade mark owner is not the sole, or even the key, driving force behind brand creation; in fact, it is actually consumers who play the vital role in this respect. Indeed, although it is true that investment by TM owners in marketing campaigns creates

\footnotetext{
${ }^{10}$ D. Gangjee, supra 5, 29.

${ }^{11}$ K.L. Keller, supra 9, J-N. Kapferer, supra 9, D. Gangjee, supra 5 and D. Desai, supra 1.

${ }^{12}$ J. Butler, supra 4, 519-523. See also R.G. Dunn, Identity Crises: A Social Critique of Postmodernity (Minneapolis: University of Minnesota Press, 1999).

${ }^{13}$ M. Callon et al., supra 4. See also M. Hamouda and A. Gharbi, 'The Postmodern Consumer: An Identity Constructor?,' (2013) 5 International Journal of Marketing Studies 41, M.E. Schramm, K.J. Trainor, M. Shanker and M.Y. Hu, 'An agent-based diffusion model with consumer and brand agents,' (2010) 50 Decision Support Systems 234 and C.K. Prahalad and V. Ramaswamy, 'Co-Creation Experiences: The Next Practice in Value Creation' (2004) 18 Journal of Interactive Marketing 5.

${ }^{14}$ P. Fawkes, supra 3.

${ }^{15}$ C. Nakassis, supra 4, 629. See also generally A. Arvidsson, Brands: Meaning and Value in Media Culture (New York and London: Routledge, 2006) and J.M. Oliveria-Castro, G.R. Foxall, V.K. James, H.B.F. Roberta, M.B. Pohl, B. Dias, S.W. Chang, 'Consumer-based brand equity and brand performance,' (2008) 28 Service industries journal 445.
} 
awareness of brands - and sometimes encourages consumer performativity of brands - much empirical evidence suggests that the TM owner often remains distant from the actual direct acts of brand-image creation which are undertaken primarily by consumers. ${ }^{16}$ Furthermore, on some occasions the agency of the TM owner is entirely absent from this process. ${ }^{17}$

Thus, by analysing the relationship between trade mark law and brands from the perspective of consumer performativity, a more vivid picture of how brand image is actually created is revealed than that which is currently accepted by the courts. This, in turn, has relevance for the second key question this article seeks to answer: who, if anyone, should own brand image? ${ }^{18}$

In the concluding part of this article I argue that, at present, European trade mark law is inadequate as a base for enabling courts to make determinations about the ownership of something as unstable and multifaceted as brand image. ${ }^{19}$

Specifically, within the twenty-first-century economy of qualities - where both individual identities and valuable brand image are in a constant state of flux - the ability of courts to make coherent legal decisions in the field of trade mark law is likely to be hindered, not helped, if the courts stubbornly persist with an outdated understanding of the relationship between trade mark owner investment and brand-image creation. ${ }^{20}$ It would be better for the law if the courts were willing to accept that brandimage creation is a complex, dialogical process, often involving the agency of both the TM owner and the consumer, but sometimes merely the consumer, and that in light of this complexity, using trade mark law to award blanket ownership of brand image to TM owners is simply unjust. In fact, it is perfectly in line with the traditional doctrine of trade mark law to say that there are aspects of brand image that do not fall within trade mark protection, and that these aspects, despite their value, ought not to be owned by anyone. In other words, the courts should not be afraid to state the obvious: the purpose of trade mark law is to protect trade marks, not every single aspect of the wider brand, a point that seems especially evident in cases where there is no harm to an underlying mark..

If the courts are unwilling to reverse course - or at the very least to provide a more convincing explanation for how brand image creation and ownership fit within the traditional boundaries of trade mark law - the best way forward would be a thorough rethink at EU policy and legislative levels with regard to what trade mark law ought to protect with respect to brand image, in light of the rise of

\footnotetext{
${ }^{16}$ K.L. Keller, 'Conceptualizing, Measuring, and Managing Customer-Based Brand Equity,' (1993) 57 Journal of Marketing 1, 1-3. See also generally D.A. Aaker, Managing Brand Equity (New York: Free Press, 1991).

${ }^{17}$ C. Nakassis, supra 4,632

${ }^{18}$ C. Grönroos, supra 3, 9-11.

${ }^{19}$ J. Butler, supra 4, and C. Nakassis, supra 4.

${ }^{20}$ M. Callon, et al. supra 4, 194-199.s
} 
anthropological marketing, bearing in mind the eternal maxim that not everything that is valuable necessarily deserves protection under the law, and that other interests, notably those of citizens, consumers, and competitors, must also be taken into account. ${ }^{21}$

\section{THE DISTINCTION BETWEEN THE TRADE MARK AND THE BRAND}

In order to make sense of the recent shift within trade mark law - from protecting mere trade marks to additionally protecting the mark's brand dimension - it is important to first highlight the difference between the nominal, symbolic trade mark (TM) and the wider concept of the brand. ${ }^{22}$ Under the TRIPS agreement, a trade mark is defined as a legally constituted sign, the defining feature of which is that it is 'capable of distinguishing the goods or services of one undertaking from those of other undertakings ${ }^{23}$ Beebe, meanwhile, views the trade mark as being 'a three-legged stool, consisting of a signifier (the perceptible form of the mark), a signified (the semantic content of the mark, such as the goodwill or effect to which the signifier refers), and a referent (the product or service to which the mark refers) ${ }^{24}$ As Gangjee argues, while in most cases the signifier can be readily identified by examining the relevant register, and the referent can be established by the list of goods/services made available by the manufacturer/provider, the notion of what is signified by the mark is much more nebulous, and it is here that the wider notion of the brand comes into play. ${ }^{25}$

\footnotetext{
${ }^{21}$ See Commission Proposal for a Regulation of the European Parliament and of the Council amending Council Regulation (EC) 207/2009 on the Community trade mark, COM (2013) 161 final (27 March 2013); Commission Proposal for a Directive of the European Parliament and of the Council to Approximate the Laws of the Member States Relating to Trade Marks, COM (2013) 162 final (27 March 2013). Within the initial proposals, there was an attempt to limit double-identity protection to origin-related scenarios: see discussion in M. Senftleben, 'Function Theory and International Exhaustion \pm Why It Is Wise to Confine the Double Identity Rule to Cases Affecting the Origin Function' (2014) 36 European Intellectual Property Rev. 518; A. Kur, 'The EU Trademark Reform Package - (Too) Bold a Step Ahead or Back to Status Quo?' (2015) 19 Marquette Intellectual Property Law Rev. 19. However, this origin-related language has since been removed: see 'Trade marks reform: Council confirms agreement with Parliament', at <http://www.consilium.europa.eu/en/press/press-releases/2015/06/10div-trade-marks/>; Proposal for a Regulation of the European Parliament and of the Council amending Council Regulation (EC) No 207/2009 on the Community Trade Mark and Proposal for a Directive of the European Parliament and of the Council to approximate the laws of the Member States relating to trade marks (Recast), at <http://data.consilium.europa.eu/doc/document/ST-9547-2015-ADD-2/en/pdf>..

${ }^{22}$ Interbrand ranks Apple the most valuable global brand for 2014, with Google and Coca-Cola second and third on the list - http://www.bestglobalbrands.com/2014/ranking/. See also D. Gangjee, supra 5, 29.

${ }^{23}$ Article 18, Agreement on Trade-Related Aspects of Intellectual Property Rights, Annex 1C of the Marrakesh Agreement Establishing the World Trade Organization (1994) (hereafter referred to as TRIPS); accessible at http://www.wto.org/english/tratop_e/trips_e/t_agm0_e.htm

${ }^{24}$ B. Beebe, supra 5, 625.

${ }^{25}$ D. Gangjee, supra 5, 30. The Office of Harmonization for the Internal Market (OHIM) registers the Community Trade Mark in the European Union - https://oami.europa.eu/ohimportal/en/ - while the UK Intellectual Property Office (IPO) registers UK Trade Marks - http://www.ipo.gov.uk/types/tm.htm
} 
The brand refers to 'the totality of the image that is portrayed in relation to or by a product in the marketplace, and the process of getting it there'. ${ }^{26}$ Thus, the brand concept encompasses not only the trade mark, but also an array of signified meanings and associations, many of which go far beyond the traditional functions associated with trade mark law. The exact content of these meanings and associations is discussed in detail later on. For now, it is sufficient to note that the brand is a much broader entity than the trade mark, and that it is a 'remarkably elusive and protean, yet undeniably valuable, intangible. ${ }^{27}$

Given the difficulty in defining the brand, the view of the UK courts has traditionally been that trade mark law - and intellectual property law more generally - does not protect every element encompassed by the brand. This was noted in an insightful statement by Lewison J. in O2 v Hutchison:

"English law does not, however, protect brands as such. It will protect goodwill (via the law of passing off); trade marks (via trade mark infringement); the use of particular words, sounds and images (via the law of copyright); and configuration of articles (via the law of unregistered design right) and so on. But to the extent that a brand is greater than the sum of the parts that English law will protect, it is defenceless against the chill wind of competition." 28

In order to fully understand why the traditional approach has been for the law to protect trade marks but not brands as such - it is necessary to reflect upon the underlying theoretical justifications for trade mark protection.

\section{THE THEORETICAL JUSTIFICATIONS OF TRADE MARK LAW}

Cornish et al. state that there are three distinct functions of a TM: origin, quality, and an overlapping set of functions related to investment, advertising and communication. ${ }^{29}$ In traditional doctrine, the key justification for trade mark protection centres on this first idea: that the mark is a guarantee of origin that protects against consumer confusion. ${ }^{30}$ The second issue - quality - is of significance in the sense that the presence of the trade mark allows the consumer to make a rational determination of the

\footnotetext{
${ }^{26}$ C. Waelde, G. Laurie, A. Brown, S. Kheria and J. Cornwell, Contemporary Intellectual Property: Law and Policy (Oxford: OUP, 2013), 553.

${ }^{27}$ D. Gangjee, supra 5, 29.

${ }^{28} 02$ v Hutchison [2006] ETMR 677 at para. 7.

${ }^{29}$ W. Cornish, D. Llewelyn and T. Aplin, Intellectual Property: Patents, Copyrights, Trademarks \& Allied Rights (London: Sweet and Maxwell, 2013), 644-645.

${ }^{30}$ Sieckmann v. Deutsches Patent- und Markenamt (C-273/00) [2005] CMLR 40. See also I. Simon Fhima, 'How Does “Essential Function” Drive European Trade Mark Law?' (2005) 36 IIC 401, H. Rosler, 'The rationale for European trade mark protection,' (2007) 29 EIPR 100, 103-107 and M.A. Lemley and M. McKenna, 'Irrelevant Confusion,' (2010) 62 Stanford Law Review 413, 413-414.
} 
likely quality of the good or service being offered, perhaps based on prior experience of similar products manufactured by the same company. ${ }^{31}$ It is the third set of functions - advertising, communication, and most crucially, investment - that is the main focus of this article, as these were the most relevant functions in the case of L'Oréal.

Undoubtedly, there is a high degree of overlap between these three notions as well as some confusion as to how they interact. The CJEU's view is that recognition of the advertising function is necessary in order to take account of the fact that marks may be used 'for advertising purposes designed to inform and persuade consumers.. ${ }^{32}$ Yet, while the advertising function is outlined coherently within European trade mark discourse, the communication function remains relatively vaguely defined. ${ }^{33}$ In fact, Gangjee argues that the communication function is 'arguably unnecessary' since it simply refers to the mark's ability to communicate content to the consumer, something that is sufficiently covered by the advertising and investment functions. ${ }^{34}$ The investment function, meanwhile, is the most significant function when it comes to brand image creation, as noted in the case of L'Oréal discussed below. ${ }^{35}$ At the most basic level, the investment function is framed around the idea that since the TM owner has invested in the mark - primarily via the funding of marketing campaigns - he or she ought to reap the rewards of this investment, and further should be allowed to prevent others from misappropriating the value which results. ${ }^{36}$

As a concept, the investment function divides trade mark scholars and jurists: ${ }^{37}$ some maintain that trade mark law should retain its traditional focus on the function of the mark as a badge of origin, while others argue that the investment function deserves protection in its own right. ${ }^{38}$ Notable within the former category is Jacob L.J., who has opined that he has 'real difficulty' with the investment function when it is 'divorced from the origin function. ${ }^{39}$ In fact, according to Jacob LJ, not only is the investment function poorly defined, it is ill-conceived: all investments in marketing and advertising by a company's competitors potentially impinge on brand image and undermine investment, yet

\footnotetext{
${ }^{31}$ See comments of Laddie J. in Glaxo Group v Dowelhurst [2000] ETMR 415 at 425-26 (Ch). See also comments of AG Jacos in Parfums Christian Dior v Evora (C-337/95) [1997] ECR I-6013; [1998] 1 CMLR 737 at para. 41 .

${ }_{32}$ Google v. Louis Vuitton Malletier et al. (C-236/08, C-237/08 and C-238/08) [2010] ETMR 30 (Grand Chamber) at para. 91-92.

${ }^{33}$ I. Simon Fhima, 'The Court of Justice's Protection of the Advertising Function of Trade Marks: an (Almost) Sceptical Analysis ' (2011) 6 Journal of Intellectual Property Law and Practice 325.

${ }^{34}$ D. Gangjee, supra $5,41$.

${ }^{35}$ D. Gangjee, supra 5, 41-42.

${ }^{36}$ F.I. Schechter, 'The Rational Basis for Trade Mark Protection,' (1926-7) 40 Harvard Law Review 813, 818819.

${ }^{37}$ H. Carty, 'Dilution and Passing Off: Cause for Concern,' (1996) 112 LQR 632.

${ }^{38}$ W. Cornish, et al., supra 29, 646.

${ }^{39}$ L'Oréal v Bellure [2010] EWCA Civ 535 at para. 30.
} 
within a competitive marketplace not all of these ought to run afoul of the law. ${ }^{40}$ By contrast, there are a number of jurists at the CJEU who have been willing explicitly to recognize the investment function. Notably, in the case of Arsenal A.G. Ruiz-Jarobo Colomer argued forcefully that other functions - such as investment - exist independently of the origin function. ${ }^{41}$ Similarly, in Mülhens Gmbh the Court of First Instance (CFI) (now known as the General Court) stated:

"The fact remains that a mark also acts as a means of conveying other messages concerning, inter alia, the qualities or particular characteristics of the goods or services which it covers or the images and feelings which it conveys, such as luxury, lifestyle, exclusivity, adventure, youth. To that effect the mark has an inherent economic value which is independent of and separate from that of the goods or services for which it is registered. The messages in question which are conveyed inter alia by a mark with a reputation or which are associated with it confer on that mark a significant value which deserves protection, particularly because, in most cases, the reputation of a mark is the result of considerable effort and investment on the part of its proprietor." ${ }^{42}$

The court's reasoning here conflates the trade mark with the wider brand concept. This is unfortunate; as noted above, the two are best viewed through separate lenses, with the brand seen as encompassing the trade mark as well as a multiplicity of other meanings and associations. Nonetheless, the central point made by the court in Mülhens Gmbh is clear: the investment function is the primary justification for the law protecting not only the trade mark, but also the wider associations encompassed by the brand, including brand image. As examined below, the decision in L'Oréal and subsequent case law confirms that this is indeed the current position of the CJEU.

\section{L'Oréal v Bellure}

The circumstances of L'Oréal v Bellure are well known, but they are worth repeating. ${ }^{43}$ In a reference from the Court of Appeal of England and Wales, the CJEU was asked to clarify the circumstances in which comparative advertising would amount to trade mark infringement. The defendant company, Bellure, operated a business model which involved the manufacture, marketing and sale of perfumes which, though costing much less to buy, smelled more or less exactly like designer perfumes (such as those sold by L'Oréal). In the advertising of these perfumes Bellure made use of a comparative list, which explicitly compared their perfumes to other brands. Bellure also used similar packaging for

\footnotetext{
${ }^{40}$ Ibid.

${ }^{41}$ Arsenal Football Club v Reed (C-206/01) [2003] ETMR 19 at para. 46.

${ }^{42}$ Mülhens Gmbh \& Co KG v OHIM (Case T-93/06) [2008] ETMR 69 at para. 26.

${ }^{43}$ L'Oréal SA v Bellure NV (C-487/07) [2009] ETMR 55.
} 
their perfumes, so to aid consumers in their search for the 'smell alikes'. L'Oréal claimed that Bellure's actions amounted to infringement of their trade marks. ${ }^{44}$

Prior to the case, it was not entirely clear whether the 'double identity' infringement provision found in Article 5(1)(a) of the Trade Marks Directive - which prohibits the use of identical marks on identical goods - could apply to cases where there was no harm or damage to any of the functions of the trade mark. ${ }^{45}$ The CJEU stated that where any of the functions - origin, quality, communication, advertising and investment - were affected, infringement could potentially occur. ${ }^{46}$

Crucially, the CJEU also gave consideration to Article 5(2) of the TM Directive, which protects against dilution of a mark with a reputation. In this context infringement occurs 'where use of that sign without due cause takes unfair advantage of, or is detrimental to, the distinctive character or the repute of the trade mark'. ${ }^{47}$ Usually, dilution of a mark occurs by the 'blurring' of its meaning or the 'tarnishment' of its reputation; ${ }^{48}$ here, however, there was no blurring or tarnishment. As Gangjee and Burrell observe:

"In other words, L'Oréal had to argue that trade mark protection can be invoked not only (1) to prevent consumer confusion (classical infringement); or (2) to preserve the attractive force of the mark (blurring or tarnishment); but also (3) in order to protect the investment made by the trade mark owner in developing its brand." ${ }^{49}$

This third argument - the investment protection argument - eventually swayed the CJEU. The CJEU stated that Bellure had taken unfair advantage of, and thus infringed, L'Oréal's mark. ${ }^{50}$ Yet, while there is little doubt that Bellure took advantage of the L'Oréal mark in its business practices, it is much less clear that this advantage ought to be seen as 'unfair' given the lack of any harm to L'Oréal

\footnotetext{
${ }^{44}$ There was no possibility of a claim regarding infringement of the L'Oréal perfumes themselves - these scents were not covered by trade mark law or copyright law.

${ }^{45}$ Article 5(1)(a) of Directive 2008/95/EC of the European Parliament and of the Council of 22 October 2008 to Approximate the Laws of the Member States relating to Trade Marks; [2008] OJ L299/25 (hereafter referred to as the TM Directive) (formerly Council Directive 89/104/EEC of 21 December 1988 to Approximate the Laws of the Member States relating to Trade Marks, [1989] OJ L40/1). See also Arsenal Football Club v Reed (C206/01) [2003] ETMR 19 at para. 46-47; Anheuser-Busch Inc v Budejovicky Budvar Narodni Podnik (C-245/02) [2004] ECR I-10989 at para. 59; and Adam Opel AG v Autec AG (C-48/05) [2007] ECR I-1017 at para. 21. ${ }^{46}$ L'Oréal SA v Bellure NV (C-487/07) [2009] ETMR 55 at para 58.

${ }^{47}$ Article 5(2) TM Directive, supra 45.

${ }^{48}$ I. Simon Fhima, 'Exploring the Roots of European Dilution,' (2012) Intellectual Property Quarterly, 25, 29. See also G. Dinwoodie, 'Dilution as Unfair Competition: European Echoes,' in R.C. Dreyfuss and J.C. Ginsburg (eds), Intellectual Property at the Edge: The Contested Contours of IP (Cambridge: CUP, 2014), 81-102, who argues that the CJEU is using trade mark law to harmonize unfair competition rules across the EU.

${ }^{49}$ D. Gangjee and R. Burrell, supra 1, 287.

${ }^{50}$ See also Mango Sport v Diknak (R 308/2003-1) [2005] 5 at para. 19, a decision of OHIM (First Board of Appeal).
} 
caused by Bellure's practices (a point emphasised by Jacob L.J. as he reluctantly applied the L'Oréal ruling when the case returned to the Court of Appeal). ${ }^{51}$ Yet, in its judgment the CJEU seemed utterly unconcerned about this issue of harm, explaining that the taking of unfair advantage occurs in the following circumstances:

"It covers, in particular, cases where, by reason of a transfer of the image of the mark or of the characteristics which it projects to the goods identified by the identical or similar sign, there is clear exploitation on the coat-tails of the mark with a reputation. ${ }^{52}$

The CJEU further stressed that trade mark law ought to prevent any 'free-rider' who attempts to 'exploit, without paying any financial compensation and without being required to make efforts of his own in that regard, the marketing effort expended by the proprietor of that mark in order to create and maintain the image of that mark. ${ }^{53}$ To some extent, the reasoning of the CJEU here seems to veer away from trade mark doctrine into German-style unfair competition principles, something that seems inappropriate in the EU trade mark context, marking, as it does, a significant shift with respect to what EU trade mark law protects. ${ }^{54}$ As Gangjee observes:

"By prohibiting conduct which allows the defendant to benefit from someone else's brand image and reputation, regardless of any harm to the image, the court has in effect recognized the brand as an independent object of proprietary rights. ${ }^{55}$

\section{PROTECTION OF BRAND IMAGE POST-L'Oreál: VIEWING BRANDS AS PROPERTY}

It is clear in the aftermath of L'Oréal that brand image - signalling attributes such as style and luxury is protectable under trade mark law. ${ }^{56}$ Although the subsequent interpretation of L'Oréal v. Bellure at $\mathrm{EU}$ and national levels indicates there may be some room for judicial manoeuvre when allegations of free-riding and questions of fair competition arise in the context of marks with a reputation, there is

\footnotetext{
${ }^{51}$ L'Oréal v Bellure [2010] EWCA Civ 535 at para 8-17.

${ }^{52}$ L'Oréal SA v Bellure NV (C-487/07) [2009] ETMR 55 at para. 41.

${ }^{53}$ Ibid., at para. 49.

${ }^{54}$ G. Dinwoodie, 'Dilution as Unfair Competition: European Echoes' in Intellectual Property at the Edge: The Contested Contours of IP, eds. R.C. Dreyfuss and J.C. Ginsburg (2014) 81, at 81-102. See, also, A. Horton, 'The Implications of L'Oréal v Bellure - a Retrospective and a Looking Forward: The Essential Functions of a Trade Mark and When is an Advantage Unfair?' (2011) 9 European Intellectual Property Rev. 550.

${ }^{55} \mathrm{D}$. Gangjee, supra $5,45$.

${ }^{56}$ The underlying reasoning of L'Oréal has been confirmed in several subsequent cases - Google v. Louis Vuitton Malletier et al. (C-236/08, C-237/08 and C-238/08) [2010] ETMR 30 (Grand Chamber) at para. 77; Die BergSpechte Outdoor Reisen und Alpinschule Edi Koblmüller GmbH v. Günter Guni, trekking.at Reisen GmbH (C-278/08) [2010] ETMR 33 at para. 31; Portakabin Ltd and Portakabin BV v. Primakabin BV (C-558/08) [2010] ETMR 52 at para. 30. See also D. Gangjee and R. Burrell, supra 1, 288-289.
} 
still much cause for concern. For one thing, the idea that ownership of the trade mark necessitates recognizing the trade mark owner's property in all aspects of brand image now appears to be a judicially accepted legal principle of EU law, despite the fact that it has not been subjected to a serious theoretical critique. ${ }^{57}$

The CJEU's ruling was based upon two linked assumptions: first, that the TM owner's investment creates brand image; and second, that trade mark law ought to protect the resulting brand image by awarding ownership to TM owners. ${ }^{58}$ Regarding the first, it appears that the CJEU simply took it for granted that the TM owner's investment in the mark directly creates all aspects of the brand, including brand image. ${ }^{59}$ It goes without saying that this notion must be probed at a much deeper level. In this regard, it is useful to refer to the work of Keller, who breaks the brand down into two concepts: 'brand awareness', a relatively stable construct which relates to 'brand recall and recognition' by consumers following investment in advertising and marketing by TM owners; and 'brand image', an unstable construct which refers to 'the set of associations linked to the brand that consumers hold in memory'. ${ }^{60}$ Clearly, it was this idea of brand image - and the unauthorised transfer of that image - rather than brand awareness, that lay at the centre of the dispute in L'Oreál. ${ }^{61}$ It is necessary, therefore, to ask the following question: does the TM owner's investment create brand image, or does it merely create brand awareness?

This leads to the second assumption: that valuable brand image must be protected by trade mark law via the award of ownership to TM owners. In the context of trade mark law, what is protected ought to fit neatly within the unique rationales and justifications which underpin the legal doctrine. Yet, the CJEU has not adequately theorized whether the protection of valuable brand image is truly justifiable under the traditional rationale for the protection of trade marks - or indeed, by any other 'authorial' rationale. ${ }^{62}$ In fact, several scholars and practitioners have criticised the CJEU's recognition of

\footnotetext{
${ }^{57}$ See Google v. Louis Vuitton Malletier et al. (C-236/08, C-237/08 and C-238/08) [2010] ETMR 30 (Grand Chamber) and Interflora, Inc \& Anor v Marks \& Spencer Plc (Case C-323/09) [2012] ETMR 1 as well as the UK cases of Whirlpool Corp. v. Kenwood [2009] EWCA Civ. 753 at para. 135 and Specsavers International Healthcare Ltd v Asda Stores Ltd (No. 2) [2012] EWCA Civ. 24 at para. 141. See also A. Kur, 'Trademarks function, don't they? CJEU Jurisprudence and Unfair Competition,' Max Planck Institute for Innovation and Competition Research Paper No. 14-05 (2014), 1, 16.

${ }^{58}$ L'Oréal SA v Bellure NV (C-487/07) [2009] ETMR 55 at para 58. See also Google v Louis Vuitton [2010] ETMR 30 at para. 92-95, Parfums Christian Dior v Evora [1997] ECR I-6013 at 6027, D. Meale and J. Smith, 'Enforcing a trade mark when nobody's confused: where the law stands after L'Oréal and Intel,' (2010) 5 Journal of Intellectual Property and Practice 96, and Max Planck Institute, Study on the Overall Functioning of the European Trade Mark System (2011), 31-32 and 97-98; accessible at http://ec.europa.eu/internal_market/indprop/docs/tm/20110308_allensbach-study_en.pdf

${ }^{59}$ Dinwoodie notes that the CJEU decision echoes that rationale of the US case International News Service $v$. Associated Press, 248 U.S. 215, 239-240 (1918) - G. Dinwoodie, supra 48, 88.

${ }^{60}$ K.L. Keller, supra 9, 2.

${ }^{61}$ A. Arvidsson 'Brands: A Critical Perspective' (2005) 5 Journal of Consumer Culture 235, 238-239.

${ }^{62}$ H. Rosler, supra 30.
} 
property in brands as being out of step with the traditional justifications of trade mark law. According to Jacob L.J. the decision of the CJEU is so expansive it effectively throws into question the entire rationale for trade mark protection. ${ }^{63}$ David Barnes, meanwhile, is sceptical of the notion that the freerider argument can justify extending trade mark protection to brand image. ${ }^{64}$ Similarly, Gangjee and Burrell argue that even if 'free-riding' occurs, in the absence of any harm 'it does not necessarily follow that the law should intervene to protect this value'. ${ }^{65}$ The old maxim still stands: the mere fact that something is valuable does not, of itself, mean that it ought to be given legal protection. ${ }^{66}$ Yet, the following statement of the post-L'Oreál situation by Cornish et al. shows how close the CJEU's rationale comes to equating value with protection:

"Marks are symbols around which investment or the promotion of a product is built and that investment is a value which deserves protection as such, even when there is no abuse arising from misrepresentations either about origin or quality." ${ }^{67}$ (emphasis added)

The second assumption of the CJEU in L'Oreál - that investment is a value which deserves protection as such - simply cannot suffice. Trade mark law, and IP law more generally, does not protect investment - it protects what directly results from investment. If investment does not create an output, there is no justification for protection. Similarly if something is created that does not originate via a person's investment it is difficult to see the justification in awarding ownership to that person.

In this context, investment in the creation of brand awareness ought not, of itself, be enough to justify the award of ownership of brand image. The process of brand image creation must be probed much more thoroughly in order to determine whether the TM owner's investment really is the primary force behind its creation. ${ }^{68}$

\footnotetext{
${ }^{63}$ See comments of Jacob LJ concerning 'harm' in L'Oréal v Bellure [2010] EWCA Civ 535 at para 8-17.

${ }^{64}$ D. Barnes, supra 5, 20-22. See also R.A. Posner, 'Misappropriation: A Dirge,' (2003) 40 Houston Law Review 621, 625 (2003) and W. Landes and R. Posner, The Economic Structure of Intellectual Property Law (Cambridge, MA: The Belknap Press of Harvard University Press, 2003), 207-208.

${ }^{65}$ Neither, for Gangjee and Burrell, does unjust enrichment provide an adequate justification - D. Gangjee and R. Burrell, supra 1, 288.

${ }^{66}$ M.A. Lemley, 'Property, Intellectual Property, and Free Riding' (2005) 83 Texas Law Review 1031. 1031-35.

${ }^{67}$ W. Cornish, et al. supra $29,644$.

${ }^{68}$ See A. Arvidsson, supra 61, 238-239.
} 


\section{CHARTING THE RISE OF ANTHROPOLOGICAL MARKETING}

For much of the twentieth century, TM owners and brand managers believed that 'through a combination of experience, insight and strategic choices' they could more or less fully control the message of the brand. ${ }^{69}$ However, the idea that consumers passively perceive a controlled brand image directed towards them has, since the 1980s, largely been abandoned in marketing theory and corporate practice. ${ }^{70}$ Today marketing literature largely rejects the view that the brand owner or manager 'exerts considerable control over the brand'; instead, it is acknowledged that the brand's image is a highly unstable intangible, the meaning of which is malleable and only meaningful - and thus, valuable - in the minds of consumers. ${ }^{71}$ In tandem with this, businesses have moved from a top-down marketing approach to actively speaking about and encouraging anthropological marketing. ${ }^{72}$

From the trade mark law perspective, this shift in marketing theory and practice is notable because it was the outdated, top-down perspective of brand image creation that held sway in L'Oreál, not the consumer-centric one that is commonly accepted today. ${ }^{73}$ Nonetheless, before the consequences of this shift are examined from perspective of trade mark law and brand image, it is necessary to consider how this shift occurred in the first place.

Although the link is not always acknowledged, much current marketing literature and practice reflects the influence of one of the key intellectual narratives that emerged in the following the 1970s; that is, the move away from stable, essentialist conceptions of identity towards postmodern, performative notions of the self. ${ }^{74}$ This shift led to the sweeping away of a set of relatively stable and deeply held core identities. ${ }^{75}$ What has emerged instead is the idea that identity is something that is formed via a continuous process of inter-textual performance or 'play'. ${ }^{76}$ Indeed, for Butler, the term performativity refers to the formation of, and continual performance of, identity. ${ }^{77}$ In this respect, performative acts

\footnotetext{
${ }^{69}$ D. Gangjee, supra 5, 36.

${ }^{70}$ K.L. Keller, supra 16 and M. Patterson and L. O'Malley, 'Brands, Consumers and Relationships - A Review,' (2006) 18 Irish Marketing Review 10, 10-11.

${ }^{71}$ H.J. Schau, A.M. Muñiz Jr. and E.J. Arnould, 'How Brand Community Practices Create Value' (2009) 73 Journal of Marketing 30, 30 and M. Blackston, 'Building Brand Equity by Managing the Brand's Relationships,' (2000) 32 Journal of Advertising Research 101, 101-105.

${ }^{72}$ P. Fawkes, supra 3.

${ }^{73}$ H.J. Schau et al., supra 71.

${ }^{74}$ J. Butler, supra 4. See also M. Catterall, P. Maclaran and L. Stevens, 'Postmodern Paralysis: The Critical Impasse in Feminist Perspectives on Consumers,' (2005) 21 Journal of Marketing Management 489 and F.A. Firat and N. Dholakia, Consuming People: From Political Economy to Theatres of Consumption (London: Routledge, 1998).

${ }^{75}$ Ibid.

${ }^{76}$ F. Jameson, Postmodernism, or, The Cultural Logic of Late Capitalism (Durham, NC: Duke University Press, 1990), 62.

${ }^{77}$ J. Butler, supra 4, 519-526. The notion of 'performativity' is usually traced in its original conception to the linguistic philosophy of J.L. Austin. However, Austin's notion of performativity is largely limited to peformative
} 
of citation - harking back to some established norm or archetype - usually take place in everyday life. ${ }^{78}$ For instance, Butler argues that a woman's gender is not something 'she' inherently (and passively) 'is'; instead it is something 'she' actively 'does' through acts of performative citation, such as the wearing of a dress, or the putting on of make-up (or by conforming to some other socialised gender norm) ${ }^{79}$ The central point is that a person's identity is not set in stone, but is actually highly malleable, reliant upon continual performative acts, some of which conform to. while others subvert, expectations and norms.

In tandem with the emergence of this destabilizing narrative concerning the performative 'self', Michel Callon et al. argue that notions of the consumer economy have also been destabilized (and subsequently reconstructed) during the past three decades. ${ }^{80}$ Of particular interest in this regard is their concept of the 'economy of qualities'. According to Callon et al., what this notion refers to is the fact that in many modern economies the nature of the product - whether it is a tangible object or a largely intangible service - is in a constant flux, yet to succeed businesses must ensure that the consumer-brand relationship is an ongoing one ${ }^{81}$ In this way, elements of postmodernist identity politics have come to influence businesses and marketers as they have shifted from a static view of the way consumers perceive brands, towards a highly reflexive perspective of the consumer economy and a anthropological approach to the way consumer-brand interaction takes place. Giving the consumer an experience which is fluid and open-ended - rather than solid and finite - is increasingly seen as important to the building up of and maintenance of brand image. ${ }^{82}$ In other words, exploiting the instability of the product experience via branding is now precisely the economy's main source of value. $^{83}$

Moreover, as the trend in marketing literature has moved away from analysis of the actions of TM owners and brand managers towards a perspective which puts consumers centre stage, the methods

speech acts, and Butler's post-modern version is much broader in scope. For discussion of Butler's performativity see A. McKinlay, 'Performativity and the politics of identity: Putting Butler to work,' (2010) 21 Critical Perspectives on Accounting 232, 234 and A. Herman, R.J. Coombe and L. Kaye, 'Your Second Life? Goodwill and the performativity of intellectual property in online gaming,' (2006) 20 Cultural Studies 184, 199. For a post-modern conception of performativity which differs from Butler's see M. Callon, 'What does it mean to say that economics is performative?,' in D. MacKenzie, F. Muniesa and L. Siu (eds.), Do Economists Make Markets? On the Performativity of Economics (Princeton: Princeton University Press, 2007), 311-357.

${ }^{78}$ J. Butler, supra 4, 525-526.

${ }^{79}$ Ibid., 519-526.

${ }^{80}$ C. Nakassis, supra, 4, 629. See also M.E. Schramm, K.J. Trainor, M. Shanker and M.Y. Hu, 'An agent-based diffusion model with consumer and brand agents,' (2010) 50 Decision Support Systems 234 and C.K. Prahalad and V. Ramaswamy, 'Co-Creation Experiences: The Next Practice in Value Creation' (2004) 18 Journal of Interactive Marketing 5.

${ }^{81}$ S. Founier, 'Consumers and their Brands: Developing Relationship Theory in Consumer Research,' (1998) 24 Journal of Consumer Research 343, 367.

${ }^{82}$ M. Callon, et al., supra 4, 211-212.

${ }^{83}$ Ibid. 
used to measure consumer engagement with brands have reflected this transition; most significantly, marketers are increasingly engaging with anthropological and sociological methodologies. ${ }^{84}$ In other words, postmodernism has had an impact not only at the level of ideas, but also of techniques. ${ }^{85}$

For instance, Rich D’Amico, Deputy Marketing Director at IKEA USA, states:

"A key thing we do is that we tend to get very close to consumers. I like to call it anthropological marketing, studying people, getting close to them, going into their homes, having conversations, reading reports, information. Understanding their needs, dreams and desires. Being the brand that helps them fulfil those needs, dreams and desires." ${ }^{86}$ (emphasis added)

Examples of this type of anthropological marketing stretch from well known brands to the obscure, from iconic brands such as IKEA, Apple, LEGO, Google and Gucci to less well known companies, such as those involved in the manufacture of French in-line roller skates. ${ }^{87}$ When Apple wheels out the latest version of the iPad, Google unveils a new operating system, or Gucci brings out a new handbag, what the company is doing is destabilizing the product, and thus the consumer experience, once more. In this context, brands act as relatively stable platforms for the 'perpetual destabilization or requalification of products'. ${ }^{88}$ Moreover, as detailed further below, within this process consumers are often encouraged to engage with brands - effectively to 'perform' them - a creative process within which some elements of the brand appear to remain stable (awareness) while other aspects remain contestable and in a constant state of re-imagination (image). ${ }^{89}$

\footnotetext{
${ }^{84}$ E. Fischer and J. Bristor, 'A feminist poststructural analysis of the rhetoric of marketing relationships' (1994) 11 International Journal of Research in Marketing 317, 317-320.

${ }^{85} \mathrm{~T}$. de Waal Malefyt, 'Understanding the Rise of Consumer Ethnography: Branding Technomethodologies in the New Economy,' (2009) 111 American Anthropologist 201, 201-202.

${ }^{86} \mathrm{P}$. Fawkes, supra 3.

${ }^{87}$ See generally R.W. Belk, and G. Tumbat, 'The cult of Macintosh,' (2005) 8 Consumption, Markets, and Culture 205 and B. Cova and V. Cova, 'Tribal aspects of postmodern consumption research: the case of French in-line roller skaters', (2001) 1 Journal of Consumer Behaviour 67.

${ }^{88}$ R.J. Foster, 'The Work of the New Economy: Consumers, Brands, and Value Creation,' 22 Cultural Anthropologist (2007), 707, 718-719.

${ }^{89}$ K.L. Keller, supra 9.
} 


\section{FROM BRAND PERFORMANCE TO CONSUMER PERFORMATIVITY - ANALYSING CO-CREATION OF BRAND IMAGE}

The impact that anthropological marketing has had on marketing research becomes clear when the concept of 'brand performance' is examined. ${ }^{90}$ Traditionally, this concerns the question of how the brand is 'performing' - in terms of market penetration and popularity - among consumers. For marketers, measuring brand performance is one of the most common methods of assessing the value of brand image. ${ }^{91}$

Within this methodology, valuable brand image is typically quantified as 'brand equity', that is, the value-added price a branded product can command when compared with a product of equivalent quality which does not carry the brand. ${ }^{92}$ A comparison of L'Oréal and Bellure neatly demonstrates this - for instance, even if Bellure were able to provide a scent to consumers of equivalent quality, consumers would be unwilling to buy their products at the same price as L'Oréal's products. There is a clear correlation between positive brand image amongst consumers and high levels of brand equity. ${ }^{93}$

Of course, with the rise of anthropological marketing the issue of how to precisely measure brand performance has become less straightforward. ${ }^{94}$ Indeed, marketing literature is sometimes ambiguous when it comes to describing what actually happens when brand performance happens. ${ }^{95}$ Similarly, regarding brand equity, while there is a broad consensus as to what it is in a general sense, there are 'several often-divergent view-points on the dimensions of brand equity, the factors that influence it, the perspectives from which it should be studied, and the ways to measure it'. ${ }^{96}$

\footnotetext{
${ }^{90}$ E. Chirani, M. Taleghan and N.E. Moghadam, 'Brand Performance and Brand Equity,' (2012) 3 Interdisciplinary Journal of Contemporary Research in Business 1033, 1033-1035.

${ }^{91}$ See generally D.A. Aaker, supra 16. See generally K.L. Keller, supra 9 and J-N. Kapferer, supra 9.

${ }^{92}$ P. Valette-Florence, H. Guizani and D. Merunka, 'The impact of brand personality and sales promotions on brand equity,' (2011) 64 Journal of Business Research 24, 24-27, J.M. Oliveria-Castroand, G.R. Foxall, V.K. James, H.B.F. Roberta, M. B. Pohl, B. Dias, and S.W. Chang, 'Consumer-based brand equity and brand performance,' (2008) 28 Service industries journal 445, 445-461.

${ }_{93}$ M. Blackston, 'Building Brand Equity by Managing the Brand's Relationships,' (2000) 32 Journal of Advertising Research 101, 101-105.

${ }^{94}$ M.S.W. Leea, J. Motion, and D. Conroy, 'Anti-consumption and brand avoidance,' (2009) 62 Journal of Business Research 169, 169-170.

${ }^{95}$ Examples of a more theoretical approach are provided by S. Leitch and J. Motion, 'Retooling the corporate brand: A Foucauldian perspective on normalisation and differentiation,' (2007) 15 Journal of Brand Management 71 and C. Hackley, "We Are All Customers Now..." Rhetorical Strategy and Ideological Control in Marketing Management Texts,' (2003) 40 Journal of Management Studies 1325.

${ }^{96}$ K.L. Ailawadi, D.R. Lehman and S.A. Neslin, 'Revenue premium as an outcome measure of brand equity,' (2003) 67 Journal of Marketing 1, 1.
} 
Yet, even where there are disagreements about how precisely to study brand performance, marketers are united in agreement that the actions of the consumer are at the heart of this process. For instance, Blackston argues that the signal aim of measuring brand performance is to discover whether consumers are forming a relationship with the brand that is meaningful for them at a personal level, because it is this which gives positive associations to the brand (image). Attributes that are typically measured as part of this analysis include the consumer's loyalty to, trust of, and emotional connection to the brand. ${ }^{97}$

Given the centrality of the consumer in this context, it is worth recalling the work of Judith Butler in considering whether the term brand performance requires a corollary in the form of 'consumer performativity'. This concept takes Butler's theory - originally put forward in the context of postmodern identity construction - and applies it in the context of consumer-brand interaction. ${ }^{98}$ Specifically, it involves asking the following question: to what extent can the consumer-brand relationship be described as a performative one i.e. brought to life by acts of identity performance and citation by consumers? In other words, does the term consumer refer to something the person merely 'is' or does it refer to something the person actively 'does'? ${ }^{99}$ Moreover, if brand image results from consumer performativity, what is the significance of the investment of the TM owner in this context? As explored below, it is in relation to these questions that the work of Constantine Nakassis becomes useful.

\section{CONSUMER PERFORMATIVITY OF BRANDS - THE KEY TO BRAND IMAGE CREATION?}

Drawing on the work of Butler, Nakassis argues that the role of the consumer within the consumerbrand relationship is highly performative; he notes that in their day-to-day behaviour consumers actively 'cite' brands to conjure up and re-enact images - of events, fantasies or experiences - in order to project a self image congruent with those images. ${ }^{100}$ As Nakassis observes:

\footnotetext{
${ }^{97}$ A. Chaudhuri and M.B. Holbrook, 'The chain of effects from brand trust and brand affect to brand performance,' (2001) 65 Journal of Marketing 81, 81-82. See also T. Munoz and S. Kumar, 'Brand metrics: Gauging and linking brands with business performance,' (2004) 11The Journal of Brand Management 381.

${ }^{98}$ C. Nakassis, supra, 4. For discussion of the destabilized subject in the aftermath of post-modernism in the consumer context see generally P. Sweetman, 'Anchoring the (Postmodern) Self? Body Modification, Fashion and Identity,' (1999) 5 Body and Society 51 and M. Featherstone, Consumer Culture and Postmodernism (2nd ed.: London, Sage Publications, 2007).

${ }^{99}$ Ibid.

${ }^{100}$ Ibid.. See also J. Derrida, Limited Inc. (Evanston IL: Northwestern University Press, 1988), 15 and R.W. Belk, M. Wallendorf and J.F. Sherry, 'The sacred and the profane in consumer behaviour: theodicy on The Odyssey’ (1989) 16 Journal of Consumer Research 1, 12-13
} 
"Making a brand part of one's life is always a contextualized performance of self image (or self-other relationality) that is like, but ultimately not, the brand's." ${ }^{101}$

Put simply, in undertaking performative acts of citation (for example, wearing a prominent brand label, driving a particular car, using a particular laptop or smartphone, taking part in a brand-endorsed competition, and so on) consumers actively make use of brands to reflect their actual or ideal perceptions of themselves, and in doing so they help to idealise the brand's image in return. ${ }^{102}$ The malleability inherent in this process, reflecting the fluidity both of the person's identity and of the brand's image, gives the consumer-brand relationship an open-ended quality, potentially encompassing an ongoing series of performances that ceaselessly give pleasure (of whatever kind) to the consumer, while simultaneously raising the status of the brand's image.

In light of this, it is no surprise that in recent years a great many brand performance case studies have focused their attention on the performative nature of consumer behaviour. ${ }^{103}$ From these studies it can be said that acts of consumer performativity can be most readily observed with respect to brands that are commonly associated with lifestyle, such as fashion, luxury goods, automobiles and information technologies. Nonetheless, Desai argues that examples of meaningful consumer-brand interaction can be found 'across a wide range of commercial industries'. ${ }^{104}$ Indeed, in the 2014 Interbrand list of most valuable brands 14 of the top 100 are in the 'automotive' sector, 12 are in the technology sector, 12 are in the 'fast moving consumer goods' sector (which includes cosmetics, such as those made by L'Oreal, as well as brands as diverse as Gillette, Kleenex, Heinz and Kellogg's), and 7 are found in the 'luxury goods' sector. ${ }^{105}$

Another point that emerges from analysis of recent studies is that consumer performativity of brands often involves social engagement with other consumers, demonstrating that a brand's image has no meaning without collectively shared references. ${ }^{106}$ Clearly, without a polity of consumers to

\footnotetext{
${ }^{101}$ C. Nakassis, supra 4, 629.

${ }^{102}$ C.R. Hollenbeck and A.M. Kaikati, 'Consumers' use of brands to reflect their actual and ideal selves on Facebook,' (2012) 29 International Journal of Research in Marketing 395.

${ }^{103}$ A. Muñiz and T. O’Guinn 'Brand community' (2001) 27 Journal of Consumer Research 412. For specific group studies see generally R.W. Belk, and G. Tumbat, supra 87 and B. Cova and V. Cova, supra 87. See also M. Laroche, M.R. Habibi, M. Richard and R. Sankaranarayanan, 'The effects of social media based brand communities on brand community markers, value creation practices, brand trust and brand loyalty,' (2012) 28 Computers in Human Behavior 1755, C. Veloutsou and L. Moutinho, 'Brand relationships through brand reputation and brand tribalism,' (2009) 62 Journal of Business Research 314 and A. Payne, K. Storbacka, P. Frow and S. Knox, 'Co-creating brands: Diagnosing and designing the relationship experience,' (2009) 62 Journal of Business Research 379.

${ }^{104}$ D.R. Desai, supra 1, 985. See also generally C. Lury, Brands: The Logos of the Global Economy (London: Routledge, 2004).

${ }^{105}$ Interbrand, supra 22.

${ }^{106}$ A.M. Muniz, Jr. and T.C. O’Guinn, 'Brand Community' (2001) 27 Journal of Consumer Research 412.
} 
individually and collectively acknowledge and sustain the brand's iconography, its image would be hollow. On this, Gangjee observes that brands 'signal social identity or status - compare those who drive trustworthy Toyotas with flashy Ferraris'. ${ }^{107}$ In Gangjee's example, Toyota automobiles are, in some people's view, 'trustworthy' (though they might also be described as 'boring') while Ferrari's cars are, in the eyes of some, 'flashy' (while they might be seen as 'exciting' by others). Necessarily, therefore, brand image creation involves the parallel existence of individual consumer performativity and collective or community brand engagement. In other words, while each individual consumer might have a personal attachment to a brand, these individuals also live their daily lies within social spaces, and thus they are aware of - and play up to - commonly recognized brand traits. ${ }^{108}$ Ultimately, the image of a brand only becomes truly iconic once it is accepted at both the individual and group levels. $^{109}$

Two recent examples of anthropological marketing and brand image co-creation resonate very clearly in this context. Coca-Cola's recent 'Share a Coke' campaign encouraged consumers to search for and to inscribe their names (and their friends' names) onto Coke cans - quite literally inserting themselves into the brand. ${ }^{110}$ Meanwhile, Nike's 2014 slogan showing England football fans wearing the Nike England shirt proclaimed 'We make the shirt - you make it matter', a statement that makes it quite clear who really creates the positive images attributable both to Nike and to England. ${ }^{111}$ In both the Coke and Nike examples there is no question that it is consumers who create the brand's fun and playful image via performative acts.

Ultimately, whether the performance is expressed at an individual or collective level, it is obvious that the so-called 'passive' consumer is largely a myth; the consumer is in fact an active, subjective person, capable of performing acts of identity and self-image via consumption. Moreover, it is this consumption that plays a large - perhaps the key - role in the creation and maintenance of brand image. To acknowledge this is not to valorize consumer behaviour in itself, but merely to recognize what is happening; and neither does this acknowledgement ignore the fact that the rapid growth of participatory consumerism over the past three decades has overlapped with a dramatic drop in active political participation (party membership, union membership, and so on) within many developed economies. ${ }^{112}$ Like it or not, consumers care deeply about brands and they often engage more

\footnotetext{
${ }^{107}$ D. Gangjee, supra 5, 35.

${ }^{108}$ R.W. Belk, and G. Tumbat, supra 87 and B. Cova and V. Cova, supra 87.

${ }^{109}$ See generally M. Kemp, Christ to Coke: How Image Becomes Icon (Oxford: OUP, 2011).

${ }^{110}$ The website for the Coca-Cola campaign is accessible at http://www.shareacoke.com/

111 The major advertisement for this Nike campaign is on YouTube

https://www.youtube.com/watch?v=6H0lu5lU7tU

${ }^{112}$ P. Ramsay, 'Faking Democracy with Prisoners' Voting Rights', LSE Law, Society and Economy Working

Paper 7/2013 (2013) 1-7, at <http://www.lse.ac.uk/collections/law/wps/WPS2013-07_Ramsay.pdf>.
} 
enthusiastically with them than they do with political parties or civil society organizations. As Fournier remarks, 'Brands cohere into systems that consumers create not only to aid in living but also to give meaning to their lives'. ${ }^{113}$

The connection between the agency of consumers and the creation of brand image is clear. One question remains, however: what role does the TM owner play in this process?

\section{IS THE TRADE MARK OWNER THE 'RING-MASTER' OF BRAND IMAGE CREATION BY CONSUMERS?}

As Keller observes, the TM-owner is clearly active in exercising agency with respect to the creation of brand awareness, by making consumers aware of the branded products which are available via investment in advertising. ${ }^{114}$ Yet, as noted above, it is the consumer's actions that are most directly linked to the creation and maintenance of brand image. ${ }^{115}$

Despite this, it is important to acknowledge that there may be a role for the TM owner as a kind of puppeteer or 'ring-master' behind the scenes. For instance, in addition to creating brand awareness, investment in advertising and anthropological marketing also sometimes encourages consumers to engage with brands at a performative level (performances which, in turn, generate brand image). For instance, in the Nike and Coca-Cola examples given above the companies' aim was clearly to encourage the development of an affective, performative relationship between the consumer and brand, and many consumers did in fact participate. ${ }^{116}$ In light of this, it is worth asking the following question: by 'performing' brands do consumers effectively become the 'puppets' of TM owners? Are their performances controlled by the TM owner ring-masters? Indeed, even if consumer agency is the key to brand image creation, are TM owners really the ones exercising the key agency after all?

There is some weight to this idea. In the context of consumer performativity, Herman et al. state that the asymmetric imbalance of power between the consumer and the TM owner ought to be obvious; notably, the TM owner encourages consumer performativity only in so far as it gives value to the

\footnotetext{
${ }^{113}$ S. Founier, supra $81,367$.

${ }^{114}$ K.L. Keller, 'Conceptualizing', supra 16, 1-3.

${ }^{115}$ Ibid.

${ }^{116}$ K. Roberts, Lovemarks: The Future Beyond Brands (New York: Powerhouse, 2004), 43. See also K. Assaf, 'Brand Fetishism' (2010) 43 Connecticut Law Review 83, J. Sheff, 'Biasing Brands' (2010) 32 Cardozo Law Review 1245 and 'What are brands for?,' The Economist (August 30th, 2014); accessible at $<$ http://www.economist.com/news/business/21614150-brands-are-most-valuable-assets-many-companiespossess-no-one-agrees-how-much-they>.
} 
brand. ${ }^{117}$ In this regard, TM owners intend for consumers to create the brand's image via performance of the brand, but the brand is not meant to become so overused by consumers that it effectively becomes 'generic'. ${ }^{118}$ The use of counterfeits is not allowed, being a clear violation of trade mark law. Furthermore, the consumer is not supposed to tarnish the brand's image in any way. ${ }^{119}$ Thus, the freedom to make of the brand whatever the consumer wishes is (apparently) tightly estricted. ${ }^{120}$

In this respect, we could view consumer performativity of brands as being based on a real, but limited, idea of freedom of expression of self-identity, with the agency of the TM-owner seemingly never far away.

In light of this, we could view consumer performativity of brands as being based on a real, but limited, idea of freedom of expression of self-identity, with the agency of the TM-owner seemingly never far away. We could view brands as inhabiting different 'orders of appearance', at times appearing to facilitate acts of performance, exuberance and playfulness by consumers, while simultaneously working as badges of conformity for behaviour that is always overseen by the TM owner. ${ }^{121}$ In this way, consumer performativity could be described as being both empowering and disempowering. empowers in the sense that it allows the consumer to shape a sense of identity (either individually or within a wider group dynamic), but it also disempowers by costing the consumer money, time, and energy. ${ }^{122}$ For this reason, Nakassis states that the brand 'always defers its promise to satisfy and thereby reproduces that very desire'. ${ }^{123}$ Similarly, Mazzarella describes this phenomenon as 'keeping-while-giving.'. ${ }^{124}$

Furthermore, although TM owners and marketers acknowledge that there is a crucial role for consumers in the creation and maintenance of brand image, and thus equity, they do not view consumers as equity partners. ${ }^{125}$ As Arvidsson argues, consumers labour to create brand value via performative acts, while simultaneously paying for the goods/services which carry the brand. ${ }^{126}$ The

\footnotetext{
117 A. Herman et al., supra 77, 187

${ }^{118}$ R.J. Coombe, The Cultural Life of Intellectual Properties: Authorship, Appropriation, and the Law (Durham, NC: Duke University Press, 1998), 79-82.

${ }^{119}$ R.J. Foster, supra 88, 724.

${ }^{120}$ Ibid., 719.

${ }^{121}$ J. Baudrillard, 'Simulations' in R. Kearney and D. Rasmussen (eds.), Continental Aesthetics - Romanticism to Postmodernism - An Anthology (Oxford: Blackwell Publishing, 2001), 411-430, 414.

${ }^{122}$ F. Jameson, supra 76, 86.

${ }^{123}$ C. Nakassis, supra 4, 634.

${ }^{124}$ W. Mazzarella, Shovelling Smoke: Advertising and Globalization in Contemporary India (Durham, NC: Duke University Press, 2003), 194.

${ }^{125}$ T. de Waal Malefyt, supra 85, 201-202.

${ }^{126}$ A. Arvidsson, supra 61, 237.
} 
practical result of this, as Foster observes, is that valuable brand image represents TM owners' 'appropriation of the appropriations of branded goods by consumers'. ${ }^{127}$

So are the TM owners, as ring-masters, the real creators of brand image, or are consumers, as the direct performers of brands, nonetheless still the crucial agents? From the perspective of trade mark doctrine and the investment function, we need to consider the question of what should count as 'investment'. Should only (financial) investment (for example, in advertising) count, or should other investments (of labour, time, imagination) made by consumers also count?

\section{WHO SHOULD OWN BRAND IMAGE? (OR, WHOSE INVESTMENT SHOULD COUNT?)}

What the above discussion inevitably leads back to is the crucial question of ownership: put simply, since both consumers and the TM owner appear to exercise some agency in the creation of a brand's image, who, precisely, should own it? As noted above, we could view the TM owner as the puppeteer or ring-master of consumer performativity of brands. ${ }^{128} \mathrm{We}$ could then say that, as the ultimate ringmasters, TM owners should in fact own any brand equity that results from consumer performativity of brands. This plausibly could be aligned with the investment function accepted by the courts in L'Oreal.

Nonetheless, it is not enough to envisage the TM-owner behind the scenes pulling all of the consumerist strings that eventually give the brand's image content and value. Consumer performativity of brands - and the building up of brand image - is not something that in all cases is overseen and controlled by the TM owner; on each occasion, the performance is different, and has different meanings, sometimes in line with TM owner's wishes, sometimes not. ${ }^{129}$

Even more important is the fact that the TM owner's agency is not always present. There are many examples of creative and subversive appropriations of brands - the terms 'brandalism', 'homage' and 'remix' are often used in such cases - by artists and by up-and-coming companies, particularly in developing countries. ${ }^{130}$ While some of these examples are critical of brands, some actually serve to increase the esteem of the brand's image. For instance, Nakassis argues that there is now an 'aesthetic of brandedness' which plays itself out very differently in the developing world, for example, in India,

\footnotetext{
${ }^{127}$ R.J. Foster, supra, 17, 718.

${ }^{128}$ R. Neate, 'How an American woman rescued Burberry, a classic British label' The Guardian, 16 April 2013, at <http://www.theguardian.com/business/2013/jun/16/angela-ahrendts-burberry-chav-image〉.

${ }^{129}$ C. Nakassis, supra 4, 634. See also S. Katyal, 'Semiotic Disobedience' (2006) 84 Washington University Law Review 489.

${ }^{130}$ B. Luvaas, 'Designer Vandalism: Indonesian Indie Fashion and the Cultural Practice of Cut 'n' Paste,' (2010) 26 Visual Anthropology Review 1, 1-5.
} 
than it does in the developed economies of Europe or the United States. Nakassis refers to examples from his field research of young, lower-middle class Indian men who wear counterfeit branded clothes in order to engage with - and perform - the brands, and who argue that wearing the 'genuine' clothes is not financially feasible for them (and that it would be seen by their peers as a socially obscene thing to do, given the large scale poverty that exists in India). ${ }^{131}$

Such subversive appropriations and counterfeits irritate TM owners because they involve consumers citing the brand 'without actually being part of the authorizing chain of production (and profit flow) that certifies the brand good'. ${ }^{132}$ Nonetheless, Nakassis notes that in circumstances where brandedness is an aesthetic in itself, the illegality of the counterfeit actually serves to bolster the image of the brand. ${ }^{133}$ In other words, in such circumstances the esteem of the brand - its image - is actually increased by examples of consumer performativity which involve counterfeits. It is reasonable to assume, therefore, that at least some brand equity is created in circumstances where not only is the agency of the TM owner absent, but where the TM owner actually opposes the specific performative acts of consumers (as violations of trade mark law). This raises serious questions about whether the link between the investment of the TM owner and brand image is truly strong enough to justify the recognition and award of ownership of every aspect of the brand's image to TM owners. ${ }^{134}$

\section{CONCLUSION}

In light of the above analysis, a number of points are worth noting. First, there is a crucial distinction between the trade mark and the brand, with the brand encompassing the trade mark but also wider attributes and associations, which are often of value. Second, these wider attributes can be sub-divided into brand awareness (largely created directly by the investment of the TM owner) and brand image (created by the direct agency of consumers as the primary performers of brands, and in some cases, but by no means all, co-created by TM owners as the secondary 'ring-masters' of these performances). Third, although trade mark law has traditionally given protection to the trade mark - but not to every positive or valuable attribute of the brand - the CJEU has recently sought to protect brand image using trade mark law, and has awarded ownership of brand image to TM owners on the basis of the TM owner's investment. Notably, in developing this expansive view of trade mark law, the CJEU has ignored the performative role of consumers as co- creators of brand image, and has instead rested its

\footnotetext{
${ }^{131}$ C. Nakassis, supra 8, 634. Penz and Stöttinger argue that sometimes people prefer counterfeits because they can be, in terms of quality, as good or better than the original - E. Penz and B. Stöttinger, 'Forget the "Real" Thing-Take the Copy! An Explanatory Model for the Volitional Purchase of Counterfeit Products,' (2005) 32 Advances in Consumer Research 568.

132 Ibid.. 632.

${ }^{133}$ Ibid., 635.

${ }^{134}$ D.R. Desai, supra 1, 992. See also D. Gangjee, supra 5, 37.
} 
internal assumptions on a stable, top-down idea of brand creation that has been entirely destabilized by recent marketing theory and practice. ${ }^{135}$

Given the complexity inherent in the dialogical process of brand image creation which, as noted above, often involves the agency of both consumers and the TM owner, as well as the maintenance of stable (brand awareness) and unstable (brand image) elements, the CJEU's blanket award of ownership of brands to TM owners seems unjust, and does not fit neatly with the stated justification of the investment function. Moreover, the ability of courts to make coherent legal decisions in the field of trade mark law is likely to be hindered, not helped, if the courts stubbornly persist with an outdated understanding of the relationship between trade mark owner investment and brand image creation. It would be better for the law if the courts were willing to accept that the role consumers play in the creation and maintenance of brand image ought to be taken into account when questions of investment, agency, and ownership arise. Indeed, in such situations it is perfectly in line with the traditional doctrine of trade mark law to say that there are aspects of the brand that do not fall within trade mark protection, and that these aspects, despite their value, ought not to be owned by anyone. ${ }^{136}$ In other words, the courts should not be afraid to state the obvious: the purpose of trade mark law is to protect trade marks, not every single aspect of the wider brand, a point that seems especially evident in cases where no harm is caused to an underlying mark.

If the courts are unwilling to reverse course - or at the very least provide a more compelling explanation for how brand image creation fits within traditional boundaries of trade mark law - the best way forward would be for the EU to undertake a thorough rethink at the policy and legislative levels of what the law should protect with respect to brands. Unfortunately, efforts to do this are often stymied by a lack of political will: for example, a recent EU trade mark reform proposal to put language into Article 10(2)(a) of the redrafted Trade Marks Directive to limit double-identity protection to origin-related scenarios failed to survive into the final package of reforms. ${ }^{137}$ Nevertheless, bearing in mind the eternal maxim that not everything that is valuable necessarily deserves legal protection, and that the law ought to take non-corporate interests - notably those of citizens, consumers and competitors - into account when questions of intellectual property arise, a strong case remains for a more substantive reconsideration of the nature and purpose of trade mark law in the aftermath of the rise of anthropological marketing.

\footnotetext{
${ }^{135}$ J. Butler, supra 4, and C. Nakassis, supra 4.

${ }^{136}$ M. Callon, et al. supra 4, 194-199.

${ }^{137}$ M. Senftleben, supra 21.
} 